\title{
„Tylko życie poświęcone innym warte jest przeżycia” Problemy zawodu lekarza
}

\author{
KAROLINA FLORCZYK
}

SWPS Uniwersytet Humanistycznospołeczny, ul. gen. Tadeusza Kutrzeby 10, 61-719 Poznań

ORCID 0000-0002-3052-0707, E-mail: karolina.florczyk@gmail.com

STRESZCZENIE: Celem artykułu jest identyfikacja ryzyka i problemów zawodowych w grupie lekarzy medycyny. W części pierwszej autorka analizowała stopień ryzyka różnych czynników: niebezpiecznych (urazowych, wypadkowych), szkodliwych (fizyczne, chemiczne, biologiczne i psychofizyczne), a także wymagania stanowiskowe i możliwości rozwoju zawodowego w Polsce. W drugiej części, na bazie dostępnych wyników badań, zostały wskazane czynniki wpływające na stan zdrowia lekarzy, określone przez warunki pracy i godziny pracy, czynniki stresujące oraz uzależnienia. W trzeciej części zostały zaprezentowane aktualne dobre praktyki i możliwe rozwiązania tych problemów, które jednocześnie są przyjazne dla lekarzy.

SŁOWA KLUCZOWE: lekarz, stres, satysfakcja z pracy, zapobieganie

\section{WSTĘP}

Zamiar podjęcia tytułowego zagadnienia zrodził się na podstawie obserwacji aktualnych wydarzeń związanych z postulatami rezydentów i ich akcji protestacyjnej oraz rozmów z lekarzami o ich pracy zawodowej. Wpływ na zdrowie i życie pacjentów może być zarówno źródłem szczególnej satysfakcji, jak i obaw wynikających z odpowiedzialności.

Niniejszy artykuł jest próbą analizy faktycznych trudności, typowych dla zawodu lekarza. W tym celu dokonano przeglądu wymagań stawianych kandydatom do pracy, analizy ryzyka zawodowego i identyfikacji zagrożeń. Następnie scharakteryzowano najważniejsze czynniki wpływające na stan zdrowia lekarzy. Są to: warunki i organizacja pracy, stres i czynniki stresujące oraz uzależnienia. W ostatniej części przedstawiono właściwe praktyki profilaktyczne oraz zaproponowano rozwiązania, które mogą ułatwić redukcję zagrożeń.

Większość dostępnych publikacji dotyczy pacjentów i efektów leczenia różnych chorób, brakuje natomiast doniesień naukowych na temat lekarzy i ich problemów, dlatego w pracy posłużono się skromną literaturą przedmiotu, a także skorzystano z informacji anonimowego autora. 


\section{CHARAKTERYSTYKA OGÓLNA ZAWODU}

Lekarza medycyny zalicza się do kategorii zawodów publicznego zaufania, wyłonionych odrębną ustawą RP z uwagi na szczególny charakter pracy. W niniejszej części omówiono szczegółowe wymagania, ryzyka i zagrożenia, jakie niesie za sobą wykonywanie tego zawodu.

Sondaż Centrum Badania Opinii Publicznej (CBOS) z 2009 roku ujawnił, że zawód lekarza został uznany przez $75 \%$ respondentów jako prestiżowy. Jednakże w ostatnim czasie sami zainteresowani mają odmienne opinie na ten temat. Odbyły się bowiem protesty, których celem było zwrócenie uwagi na złą kondycję i warunki pracy w służbie zdrowia. Podkreślano, że polska służba zdrowia jest najgorzej finansowania w całej UE, ma najniższą liczbę lekarzy na tysiąc pacjentów, cierpi na długie kolejki do specjalistów oraz rozbudowaną biurokrację redukującą czas na diagnostykę i rozmowę z pacjentem, a ponadto lekarze są nisko wynagradzani. Wskazano również na problemy organizacyjne w zakresie kontynuacji kształcenia, gdyż co roku maleje liczba miejsc na staże specjalizacyjne. W konsekwencji może to doprowadzić do jeszcze mniejszej liczby specjalistów, a jednocześnie zwiększyć liczbę absolwentów uczelni medycznych wyjeżdżających z kraju, którzy z powodu braku miejsc nie będą mogli pracować w Polsce, co pozbawi ich prawa do wykonywania zawodu.

\section{WYMAGANIA}

Kandydat na lekarza medycyny rozpoczyna edukację od sześcioletnich studiów na wydziale lekarskim, które to studia mają identyczny program niezależny od przyszłej specjalizacji. Należy wskazać, że w programie studiów brakuje elementów związanych z kształtowaniem umiejętności komunikowania się z pacjentem czy zarządzania stresem. Po pomyślnym ukończeniu medycyny, absolwent otrzymuje ograniczone prawo do wykonywania zawodu od Krajowej Izby Lekarskiej w danym województwie i zobowiązany jest odbyć wymagany staż lekarski. Staż trwa trzynaście miesięcy i kończy się lekarskim egzaminem końcowym (państwowym), który daje prawo do wykonywania zawodu. Z wynikiem pozytywnym można ubiegać się w wojewódzkich centrach zdrowia publicznego o szkolenie specjalizacyjne, które trwa od czterech do sześciu lat w zależności od wybranej dziedziny. Szkolenie jest poprzedzone rozmową kwalifikacyjną i skutkuje umieszczeniem lekarza na odpowiedniej liście rankingowej. Warto nadmienić, że ów proces odbywa się tylko dwa razy w roku oraz że obecnie zarejestrowanych jest 40 specjalności podstawowych i 28 szczegółowych (Dz. U. 1997, nr 28, poz. 152).

Podsumowując, kandydat na lekarza medycyny musi wykazać się dużą wiedzą, aby uzyskać wymaganą liczbę punktów i stać się studentem kierunku lekarskiego. Następnie powinien wykazać się determinacją do kształcenia i otrzymania pełnych praw do wykonywania zawodu w celu wyspecjalizowania się w danej dziedzinie medycyny. Warto również zauważyć, że obowiązkowy staż lekarski następuje bezpośrednio po studiach, w trakcie których absolwent nabywa ogólną wiedzę medyczną uzupełnioną jedynie miesięcznymi praktykami, które odbywają się przez cały okres studiów. Ponadto nie każdy lekarz ma zagwarantowane stanowisko rezydenta, co sprawia, że musi szukać miejsca pracy na własną rękę lub pracować w ramach 
wolontariatu, co oznacza brak wynagrodzenia przez cały okres specjalistycznego kształcenia.

\section{ANALIZA RYZYKA ZAWODOWEGO}

Stosunkowo mało jest publikacji na temat analizy ryzyka zawodowego, choć w obecnej sytuacji polskiej służby zdrowia zagadnienie to staje się coraz częściej dostrzegane. Ocena ryzyka zawodowego jest obowiązkiem pracodawcy, zgodnie z Dyrektywą 89/391/EWG oraz art. 226 Kodeksu Pracy. Trudności z oceną stanu zdrowia lekarzy wynikają z braku rzetelnych danych liczbowych. Zresztą także sami medycy przez długie lata nie byli zainteresowani tym zagadnieniem. Jednakże ostatnie postulaty rezydentów wskazują na zmianę tego podejścia. Ponadto śmierć kilku lekarzy w trakcie dyżurów potraktowano jako sygnał, iż powinny być wypracowane systemowe zmiany chroniące zdrowie lekarzy.

Wskazując na czynniki ryzyka, należy zwrócić uwagę nie tylko na te, które istnieją od wielu lat, ale także na nowe. W zawodzie lekarza występują czynniki niebezpieczne, typu: urazy czy wypadki; czynniki szkodliwe: fizyczne, chemiczne, biologiczne i psychofizyczne (Irzyniec, Konodyba-Szymański, Szczerba 2010). Mimo małej liczby zanotowanych wypadków przy pracy, wskazuje się na takie urazy, jak skaleczenie, zakłucie czy zacięcie, które są bardzo niebezpieczne ze względu na zakażenia krwiopochodne. Niestety brakuje precyzyjnych danych liczbowych na ten temat, mimo że skutki urazów okazują się kluczowe dla lekarzy, gdyż często uniemożliwiają pracę zawodową.

Codzienne funkcjonowanie może także utrudnić obciążenie układu mięśniowoszkieletowego $\mathrm{w}$ trakcie wielogodzinnej pracy w wymuszonej pozycji, typowej np. dla operacji otwartych i zabiegów laparoskopowych. Fizyczne czynniki ryzyka można podzielić na dwie grupy. Do pierwszej zalicza się narażenie na hałas, mikroklimat, oświetlenie, zapylenie itp., z kolei do drugiej nowe zagrożenia, jak promieniowanie jonizujące, dym i pyły ze związkami toksycznymi i wirusami czy emisja ciepła związana z technikami laserowymi. Lekarze dentyści są ponadto narażeni na drgania i promieniowanie ultrafioletowe (Irzyniec i in. 2010). Należy dodać także obciążenie zmysłu wzroku związane z operacjami laparoskopowymi czy z pracą pod mikroskopem. Chemiczne elementy ryzyka to środki dezynfekujące i leki, a także gazy anestezjologiczne z nieszczelnych urządzeń (Irzyniec i in. 2010).

Najpoważniejszym zagrożeniem są jednak czynniki biologiczne, czyli możliwość zarażenia się i zakażenia krwiopochodne (wirusy HBV, HCV oraz HIV) oraz mikroorganizmy przenoszone we frakcji bioaerozolu (Irzyniec $i$ in. 2010).

Wszystkie wymienione czynniki wpływają na, rzadko opisywany w literaturze fachowej i równie rzadko badany, aspekt psychofizyczny, w którego obrębie wymienia się stres chroniczny i traumatyczny. Stres chroniczny jest rozumiany jako wywołany stresorem o ciągłej i stałej sile, działającym przez dłuższy czas. Stres traumatyczny jest wywołany przez bardzo silny czynnik powodujący gwałtowne, negatywne skutki (Dudek 2012). Dla zawodu lekarza charakterystyczne są wysokie oczekiwania ze strony pacjentów, brak wpływu na warunki pracy i organizację służby zdrowia oraz niskie wsparcie społeczne (Widersztal-Bazyl 2003 za Dudek 2012). Ponadto lekarze, mimo kompleksowego wysiłku, nie uzyskują satysfakcjonujących 
nagród w postaci adekwatnego wynagrodzenia, co również może skutkować wzrostem poziomu stresu (Dudek 2012). Poziom zarobków oczekiwanych w tym zawodzie jest związany z pracą równą 200-300 godzin miesięcznie.

Do czynników wpływających na kondycję lekarza medycyny, a niewymienionych w przytoczonej analizie ryzyka, należy dodać warunki pracy. Chodzi o zaburzenia rytmu dobowego związanego z nienormowanymi godzinami pracy, nieregularne pory posiłków oraz nieregularny i krótki, bądź przerywany, sen. Ponadto duże znaczenie mają obciążenia emocjonalne związane $\mathrm{z}$ odpowiedzialnością za pacjentów, spowodowane narastającą $\mathrm{w}$ ostatnim czasie liczbą procesów sądowych związanych z błędami lekarskimi. W przytoczonej powyżej analizie ryzyka wskazano na zmniejszające się wsparcie społeczne oraz na problem narastającej agresji ze strony pacjentów czy członków rodziny wobec lekarzy. Zdarzały się przypadki nie tylko napaści słownej, ale także fizycznej. Należy zwrócić również uwagę na emocje, takie jak poczucie winy czy bezradności, które mogą wpłynąć na stan psychofizyczny medyka. Warto zauważyć, że lekarz zobowiązany jest opanować nie tylko własne emocje, ale także emocje ujawniane podczas trudnych rozmów z pacjentami bądź z ich rodzinami. Dodatkową trudność może stanowić obowiązek opieki medycznej nad pacjentem nietrzeźwym lub pozostającym pod wpływem substancji psychoaktywnych czy zaniedbanym higienicznie.

Swoistą odpowiedzią na sytuację w polskiej służbie zdrowia jest zjawisko emigracji lekarzy, które prowadzi do jeszcze większych ograniczeń i obciążeń organizacyjnych (Irzyniec i in. 2010). Mimo trudności związanych z oceną stopnia ryzyka w zawodzie lekarza, okazuje się, że czynnik psychofizyczny należy uznać za najistotniejsze zagrożenie dla jego pracy, gdyż pozostałe czynniki ostatecznie i tak wpływają na stan psychiczny medyka.

\section{IDENTYFIKACJA ZAGROŻEŃ}

Badanie ankietowe lekarzy (pracujących głównie w szpitalach) przeprowadzono w latach 20042008 w trakcie kursów odbywanych w Katowicach, gdzie czynnik psychofizyczny uznano za najbardziej narażający lekarza na utratę zdrowia i życia. Na drugim miejscu wymieniono czynnik biologiczny. Ponadto jeden na czterech lekarzy wskazał na nieakceptowalny stopień stresu, uzasadniający konieczność profilaktyki. Tymczasem 61\% kierowników placówek medycznych nie dostrzega problemu bezpieczeństwa i ochrony zdrowia personelu medycznego, mimo że przepisy BHP wymagają nie tylko analizy ryzyka zawodowego, ale także działań profilaktycznych mających obniżyć jego poziom zagrożenia (Irzyniec i in. 2010). Jako dobry przykład profilaktyki można wskazać działania Śląskiej Izby Lekarskiej, która w 2009 roku przeprowadziła analizy dat zgonów 600 lekarzy i wykazała, że lekarz płci męskiej żyje krócej niż statystyczny Polak o 2,4 lata, natomiast lekarz płci żeńskiej krócej niż statystyczna Polka o 11,6 lat $^{1}$.

1 Informacja pochodzi od anonimowego autora, przekazana dnia 29.02.2018. 


\section{CZYNNIKI WPŁYWAJĄCE NA STAN ZDROWIA LEKARZY UZALEŻNIENIE OD ALKOHOLU I INNYCH SUBSTANCJI}

Codzienna praca lekarza jest narażona na wiele trudnych sytuacji, co powoduje zagrożenie stosowaniem ucieczkowych (unikowych) metod radzenia sobie ze stresem, jak np. picie alkoholu czy zażywanie substancji psychoaktywnych. Ta ostatnia możliwość jest szczególnie niebezpieczna z uwagi na łatwy dostęp do leków. W 2008 roku opublikowano wyniki badań (Szczyrba-Maroń, Wons 2008), które wykazały, że spośród 80 lekarzy, doświadczających trudnych sytuacji, 63\% sięga po alkohol, a 45\% zażywa leki uspokajające i nasenne. Autorki podają, że w trakcie pracy lekarze stosują również takie środki, jak gaz rozweselający czy kokainę, aby zachować stan gotowości podczas dyżuru. Powołując się na Avery’ego i współpracowników, podają też, iż ok. 10-15\% lekarzy jest uzależnionych od alkoholu, a ok. $60 \%$ korzysta z niego w celach relaksacyjnych. Niestety nie ma dokładnych danych liczbowych na temat uzależnień wśród lekarzy w Polsce czy na świecie.

Szczególnie ważne jest podkreślenie, że zgodnie z koncepcją Hobfolla (Heszen 2013) czynnikiem najbardziej zagrażającym własnemu zdrowiu jest inwestowanie osobistych zasobów bez pozytywnych rezultatów oraz to, że lekarze sami oceniają własny stan psychiczny jako niezadowalający (Wallace, Lemaire 2007). Warto wskazać, że stosowanie leków i alkoholu zaczyna się już w trakcie studiów medycznych (Szczyrba-Maroń, Wons 2008).

Jak podają Marcinkowski i Olejniczak (2006), problemy lekarzy są wyjątkowe ze względu na odpowiedzialność, jaka na nich ciąży, oraz z uwagi na to, że ich nałóg zostaje ujawniony dziesięć lat później niż w innych zawodach. Jako przyczyny nałogu wskazują: wysokie wymagania wobec siebie, odpowiedzialność za pacjenta i skutki leczenia, łatwy dostęp do leków, obciążenie nauką oraz nieregularny czas pracy. Autorzy podkreślają, że to lekarz był inicjatorem utworzenia grup AA, oraz że posiadana przez niego wiedza o nałogach i ich leczeniu nie chroni przed uzależnieniami. Podobne wnioski formułuje anonimowy autor ${ }^{2}$ badający lekarzy w Polsce, który twierdzi, że nie są oni diagnozowani i leczeni z uzależnień, a jedynym narzędziem walki z nałogiem jest orzeczenie o ,śmierci zawodowej”, co nie stanowi dobrego rozwiązania, a co należy także traktować jako ostateczność. Dość często problem uzależnienia rozpoczyna się w trakcie studiów, w pracy zawodowej spotyka zaś z brakiem prawidłowych reakcji, tj. z milczącym przyzwoleniem, wręcz „kryciem”, polegającym na zastępowaniu uzależnionego lekarza w pracy, co należy ocenić jako współuzależnienie ${ }^{3}$.

\section{WARUNKI I ORGANIZACJA PRACY}

Organizacja pracy placówek medycznych często jest przyczyną nieregularnego trybu życia lekarzy, który skutkuje zaburzonym rytmem snu i czuwania (Kalat 2017). Choć ów rytm biologiczny jest odporny na różne zakłócenia, dzięki m.in. białkom per i tim, to czynnikiem, który może dez- $i$ aktywować owe białka jest światło. Praca w nocy nie ma dużego wpływu na zmiany rytmu okołodobowego, głównie z uwagi na światto stosowane w szpitalach. Jednakże

2 Informacja pochodzi od anonimowego autora, przekazana 30.05.2012.

3 Informacja pochodzi od anonimowego autora, przekazana 30.05.2012. 
osoba próbująca spać w dzień, śpi krócej, chyba że znajduje się w ciemnym pokoju. Dlatego u lekarzy narażonych na regularne niedosypianie obniża się jakość funkcjonowania. Ponadto, jeśli budzi się czlowieka będącego w fazie snu REM, odczuwa on negatywne skutki w postaci przejściowej drażliwości, zwiększonego niepokoju oraz gorszej koncentracji (Kalat 2017). Można zatem stwierdzić, że budzenie lekarzy w nocy, lub calkowity brak snu i próby spania przy świetle dziennym, niekorzystnie wpływaja na ich kondycję psychofizyczna.

Należy także dodać, że nieregularne pory posiłków oraz - w przypadku specjalizacji związanych w wykonywaniem kilkugodzinnych operacji - niemożność picia, mogą mieć wpływ na zaburzenie homeostazy i stanu zdrowia (Kalat 2017).

W 2016 roku zestawiono skutki społeczne, biologiczne i zdrowotne grupy pracowników zmianowych (m.in.) z sektora opieki zdrowotnej (Stryjewski, Kuczaj, Domal-Kwiatkowska, Mazurek, Nowalany-Kozielska 2016). Okazało się, że lekarze, ze względu na organizację pracy, mają utrudnione życie i kontakty rodzinne, towarzyskie, a także możliwość korzystania z aktywnego wypoczynku czy udziału w życiu społecznym. Do biologicznych skutków zaliczono: wykonywanie pracy umysłowej w porze nocnej, niezgodność faz rytmu czynności fizjologicznych (takich jak praca układu pokarmowego w postaci trawienia posiłków ze względu na nietypowe pory ich przyjmowania, niepełnowartościowość snu, zmiany w rytmie dobowym itp.). Do skutków zdrowotnych zaliczono (Stryjewski i in. 2016: 514):

- ,choroby układu pokarmowego w postaci: bóle nadbrzusza, zgaga, zaburzenia perystaltyki jelitowej, choroba wrzodowa, zespół metaboliczny;

- schorzenia układu krążenia (choroba wieńcowa, nadciśnienie tętnicze);

- schorzenia onkologiczne;

- zaburzenia neuropsychiatryczne (zaburzenia nerwicowe, stany lękowe, depresje, lekomanie);

- zaburzenia snu (zmiany w wydzielaniu hormonów, różne postacie bezsenności, deficyt snu)".

Problemy jelitowo-żołądkowe stwierdza się 2-3 razy częściej w grupie pracującej o różnych porach dnia, a także 2-5 razy częściej, gdy praca ma miejsce w nocy. Wymieniono także chorobę wrzodową i zespół drażliwego jelita jako występujące w tych grupach 2-5 razy częściej. Na podstawie danych z badania przeprowadzonego wśród ok. 27 tys. osób zatrudnionych w systemie zmianowym stwierdzono, że tego typu praca wpływa na częstsze pojawienie się zespołu metabolicznego i otyłości niż u osób pracujących tylko w dzień (Stryjewski i in. 2016). Autorzy przywołali też wyniki metaanalizy 17 badań i stwierdzili, iż ryzyko zachorowania na choroby układu krążenia zwiększa się o około $40 \%$ przy pracy zmianowej.

W przypadku chorób nowotworowych wyniki badań pokazują, iż deprywacja snu i sztuczne oświetlenie są odpowiedzialne za wzmożony wzrost komórek rakowych (Blask, Dauchy, Sauer, Krause, Brainard 2003). Wśród zaburzeń neuropsychiatrycznych najczęściej pojawiają się epizody depresyjne (Stryjewski i in. 2016). Anonimowe źródło ${ }^{4}$ wskazuje również na częstszą zapadalność na choroby afektywne wśród mężczyzn-lekarzy, mimo że w kontekście całej populacji jest odwrotnie. Autor podkreśla, że przebieg choroby jest gorszy z uwagi na 4 Informacja pochodzi od anonimowego autora, przekazana 30.05.2012. 
opóźnione leczenie, a przy tym występuje dużo większe ryzyko popełnienia samobójstwa. Praca lekarzy, obsługujących specjalistyczny sprzęt lub lekarzy operujących, wiąże się z koniecznością zajmowania wymuszonej pozycji i wykonywania powtarzalnych czynności. Szczególnie narażony jest wówczas układ i narządy ruchu oraz wzrok, jak np. przy operacjach z użyciem nowoczesnego sprzętu laparoskopowego, czy w przypadku dentystów - mikroskopu.

Ponadto praca lekarzy wymaga stałego kontaktu z tak silnym alergenem, jakim jest lateks, mogący uczulać zarówno kontaktowo jak i wziewnie. Taka alergia może oznaczać „śmierć zawodową" lub nieść duże utrudnienia, bo choć istnieją inne materiały (np. winylowe czy nitrylowe), to nie każdy ze współpracujących będzie też takich używał ${ }^{5}$, w koncu nie każdy zgodzi się na regularne wietrzenie pomieszczeń. Stosowane są nawet specjalne opaski informujące o alergii, aby w sytuacji udzielania pomocy takiej osobie nie używać uczulających rękawiczek lateksowych. Jak podaje na swojej stronie Center of Desease Control and Prevention z Atlanty, problem dotyczy ok. 8-12\% pracowników służby zdrowia. Innym istotnym, aczkolwiek często pomijanym, aspektem jest praca polegająca na regularnym operowaniu pacjentów. To powoduje nie tylko duże obciążenie psychiczne, lecz także obciążenie fizyczne. Wszak lekarz operuje w pozycji stojącej, a operacje nie mogą być przerywane, czego efektem jest stanie przez wiele godzin bez możliwości zmiany pozycji ciała.

W przykładowym wykazie chorób zawodowych dotyczących personelu szpitalnego zarejestrowano 394 przypadki chorób zawodowych, z czego 15\% dotyczyło lekarzy, a 47\% pielęgniarek. Prawie 74\% przypadków to choroby zakaźne i inwazyjne - w większości chodziło o wirusowe zapalenie wątroby. Na drugim miejscu wymieniono choroby skóry, w tym $73 \%$ to reakcje uczuleniowe na lateks. W trzeciej grupie znalazły się choroby narządu ruchu (Peplońska, Szeszenia-Dąbrowska 2001).

\section{STRES I CZYNNIKI STRESUJACE}

Jak pokazują aktualne badania i prace psychologów, stres traktowany przez doświadczającego go jako pozytywny i mobilizujący pozostaje bez wpływu na fizjologię (McGonigal 2015). Jednak stres przewlekły i postrzegany jako negatywny wywiera istotny wpływ na pracę układu odpornościowego, pokarmowego, krążeniowo-oddechowego i hormonalnego (Heszen 2013). Człowiek potrafi skutecznie przezwyciężyć stres w sytuacji zachowywania się zgodnie ze swoimi wartościami i posiadania wpływu na sytuację (Heszen 2013). Jak podaje anonimowy informator ${ }^{6}$, w zawodzie lekarza odporność psychiczną obniżają takie sytuacje, jak: zagrożenie życia, nieuleczalne choroby, cierpienie przewlekle chorych, zgony pacjentów. To wpływa negatywnie na poczucie kompetencji medyka i przekonuje go o braku wpływu na pewne sytuacje, co z kolei nie jest obojętne w odniesieniu do samooceny, poczucia winy i odpowiedzialności ${ }^{7}$.

Potwierdzeniem tych opinii mogą być wyniki badań przeprowadzone przez zespół ze Śląskiej Akademii Medycznej w 2006 roku wśród 158 lekarzy z tego województwa (Jośko i in. 2006). Poczucie bezradności z powodu niemożności udzielenia skutecznej pomocy towarzyszyło 5 Zgodnie z informacją uzyskaną od anonimowego pracownika służb medycznych w czerwcu 2018. 6 Informacja pochodzi od anonimowego autora, przekazana 30.05.2012.

7 Informacja pochodzi od anonimowego autora, przekazana 30.05.2012. 
ok. $28 \%$ badanym. Nie radziło sobie ze stresem $47 \%$ lekarzy, $39 \%$ oceniło poziom stresu na poziomie 5,29\% - a więc na poziomie 4 (w skali od 1 do 5). Należy też uwzględnić, że w przypadku stresu i sytuacji krytycznych związanych z odpowiedzialnością za operacje ratujące życie, widok poważnych uszkodzeń ciała czy gwałtownych reakcji rodzin pacjentów, może „sensytyzować” lekarzy. Niezbędna jest więc umiejętność konstruktywnego radzenia sobie z takimi reakcjami (Kalat 2017).

Jak wspomniano w rozdziale pierwszym, w Polsce często lekarze pracują w ramach własnej działalności, nie zaś zatrudnienia na etacie. W 2009 roku poddano analizie następstwa zdrowotne pracy w więcej niż jednej placówce medycznej (Ostrowski 2009). Zbadano 411 lekarzy różnych specjalizacji z południowej Polski, spośród których 2/3 pracowało w kilku miejscach. Stwierdzono, że lekarze pozostający w związku małżeńskim częściej wybierają taką ścieżkę zawodową. Ciekawe jest to, że w tej grupie nie stwierdzono zaburzeń somatycznych, co uzasadnia się stanem mobilizacji i wysokim poziomem motywacji, ukierunkowanej na polepszenie bytu rodziny.

Natomiast praca w kilku placówkach istotnie zwiększa odczuwanie stresu zawodowego. Za główne przyczyny uznano: brak nagród, brak kontaktów społecznych, nieprzyjemne warunki pracy oraz brak wsparcia społecznego (Ostrowski 2009). Lekarze pracujący w kilku placówkach spędzają znacząco mniej czasu w każdej z nich, nie mają więc możliwości budowania relacji z pozostałym personelem medycznym czy konsultacji swych diagnoz i metod leczenia. Autor zwraca również uwagę na czynnik wyjątkowo stresogenny, jakim jest odpowiedzialność za ludzi, nierozerwalnie związana z zawodem lekarza.

Stres może wynikać z różnych czynników, lecz jednym z bardziej drastycznych dla lekarzy jest agresja ze strony pacjenta lub zespołu. Ten problem zbadano w 2009 roku wśród 501 lekarzy z województwa podlaskiego. Wykazano, że źródłem stresu ze strony pacjentów jest groźna postawa (53\%) i szantaż (41\%), z kolei ze strony przełożonych są to wulgarne wypowiedzi przy współpracownikach (18\%) oraz pogróżki (17\%). Wymieniono także podnoszenie głosu (Kowalczuk i in. 2009).

Przytoczone wyniki badań mogą uzasadniać rosnące problemy w polskiej służbie zdrowia i coraz większe niezadowolenie z warunków pracy, czemu dali wyraz w ostatnich miesiącach lekarze rezydenci, a o czym także wskazuje rosnąca liczba lekarzy wyjeżdżających za granicę.

Kolejnym czynnikiem stresującym jest praca z pacjentami przewlekle chorymi i ich rodzinami, szczególnie narażająca na zjawisko wypalenia zawodowego (Maslach 2001). Oprócz wcześniej wymienionych czynników stresujących, lekarze mają w tym przypadku do czynienia z pacjentami cierpiącymi i umierającymi. Stały kontakt z nimi powoduje narażenie na przewlekły stres, związany ze szczególnymi wymaganiami wobec lekarza, jakimi są: większe poczucie odpowiedzialności, bardzo dobre umiejętności komunikacyjne, współtowarzyszenie w cierpieniu i umieraniu, frustracja i smutek z powodu niemożności uleczenia pacjenta, brak dostępu do innych metod leczenia niż finansowane w Polsce (Kulik 2008).

Zbadano 84 lekarzy różnych specjalizacji, którzy mają do czynienia z osobami przewlekle chorymi, i stwierdzono, że nie doświadczają znacznego wypalenia zawodowego, natomiast 
charakteryzuje ich niechęć do zawierania nowych znajomości, wycofanie z relacji społecznych, wąskie kontakty interpersonalne (Kulik 2008). Spośród zbadanych neurologów, kardiologów, ortopedów i endokrynologów, jedynie neurolodzy wykazali wyższe niż przeciętne wypalenie zawodowe. Ponadto zauważono, że osoby mające wysokie poczucie własnej skuteczności są mniej wypalone zawodowo. Do wymienionych czynników należy dodać aspekt osobisty związany z tym, że obcowanie na co dzień ze śmiercią budzi refleksje na temat własnej przemijalności.

Do grona czynników stresujących zalicza się także styl życia. W badaniach przeprowadzonych w roku 2015 wśród 523 lekarzy z całej Polski stwierdzono, że styl ich życia nie różni się od innych grup zawodowych pod względem zachowań prozdrowotnych, rozumianych jako: unikanie używek, pozytywne praktyki zdrowotne (np. ćwiczenia fizyczne, odpowiednia ilość snu, używanie filtrów przeciwsłonecznych, częste mycie zębów), zwyczaje żywieniowe (ilość i jakość spożywanych produktów), bezpieczeństwo komunikacyjne (np. używanie pasów bezpieczeństwa, bezpieczna prędkość, trzeźwość), zachowania profilaktyczne (np. badania kontrolne, pomiar ciśnienia tętniczego, samobadanie piersi i jąder, badania cytologiczne). U jednej trzeciej badanych stwierdzono zachowania zagrażające zdrowiu i wykazano, że tendencja do zachowań antyzdrowotnych rosła o 3,2\% z każdym rokiem od ukończenia specjalizacji (Bąk-Sosnowska, Kołodziej, Gojdź, Skrzypulec-Plinta 2015). Jak podają autorzy, zachowania antyzdrowotne charakterystyczne dla lekarzy, to: niedobór snu, wypoczynku i aktywności fizycznej, nadużywanie alkoholu, niewłaściwa dieta, brak profilaktyki zdrowotnej.

Przytoczone wyniki badań mogą uzasadniać rosnące problemy w polskiej służbie zdrowia i coraz większe niezadowolenie z warunków pracy, czemu po raz kolejny dali wyraz w ostatnich miesiącach lekarze rezydenci i o czym wskazuje rosnąca liczba lekarzy wyjeżdżających za granicę.

Podsumowując analizę zagrożeń i doświadczanych problemów, należy zwrócić uwagę na to, że warunki i organizacja pracy personelu medycznego istotnie wpływają na samopoczucie psychiczne i fizyczne lekarzy, co może skutkować słabszą dyspozycją ogólną, chorobami zawodowymi i błędnymi decyzjami. Okazuje się również, że w kontaktach z pacjentami i pozostałym personelem medycznym duże znaczenie ma jakość wzajemnych relacji. Ze względu na status lekarza w społeczeństwie dodatkowym obciążeniem jest problem uzależnień związany z wyższymi oczekiwaniami od tej grupy zawodowej. Wszak ustawowo lekarz bierze na siebie odpowiedzialność za życie i zdrowie drugiego człowieka, a tymczasem bywa, że sam nie jest wolny od problemów zdrowotnych. Dlatego należy zwrócić uwagę na to, że nawet w środowisku medycznym nie mówi się otwarcie o problemach opisanych w tym rozdziale, a co więcej - nie prosi się o wsparcie ze strony specjalistów.

\section{LEPIEJ ZAPOBIEGAĆ NIŻ LECZYĆ DZIAŁANIA PROFILAKTYCZNE}

Problem zapobiegania uzależnieniom należy uznać za wyjątkowo trudny ze względu na rokowania, bowiem $m$ później rozpoczęte leczenie, tym trudniej opanować nałóg. W 
odniesieniu do lekarzy może to się wiązać z poważnymi konsekwencjami, aż do utraty prawa do wykonywania zawodu. Dobrą praktyką jest rozwiązanie stosowane przez Śląską Izbę Lekarską, która powołała pełnomocnika do spraw zdrowia lekarzy. Do tej osoby może zgłosić się każdy lekarz z okręgu, z gwarancją poufności i tajemnicy lekarskiej. Problem uzależnienia mogą zgłosić też członkowie rodziny, a także - na pewnych warunkach - pracodawca. Działania pełnomocnika obejmują: konsultacje indywidualne, współpracę z ośrodkami terapii uzależnień, monitorowanie stanu zdrowia lekarzy, edukację profilaktyczną ${ }^{8}$.

Uważam, że stworzenie takiej możliwości w każdej okręgowej izbie lekarskiej byłoby systemowo skutecznym wsparciem dla lekarzy - swoistym środkiem zapobiegania uzależnieniom. Ponadto zakładam, że zakres działań pełnomocnika należałoby rozszerzyć o przeciwdziałanie wypaleniu zawodowemu, depresji i innym problemom psychicznym lekarzy.

Kompetencje osobiste, które nie są weryfikowane w trakcie naboru na studia lekarskie, jawią się jako równie ważne co wiedza i umiejętności medyczne. Jak stwierdzono (Nowaczyk, Stanisić, Rzepa 2016), umiejętności komunikacyjne są kluczowe ze względu na liczbę kontaktów z pacjentami i mogą być przyczyną wypalenia zawodowego, zwłaszcza ze względu na duże oczekiwania społeczne. Jak między innymi ustalono, $50 \%$ pacjentów po wyjściu z gabinetu nie wiedziało, jak przyjmować przypisane leki, co może mieć poważny wpływ na skutki leczenia. Inny zespół wskazał, iż za przyczynę 70\% błędów medycznych uznaje się nieskuteczną komunikację między lekarzem a pacjentem (Marcinkowska, Lau, Jośko-Ochojska 2013).

Wskazano, że doświadczanie stresu wpływa negatywnie na myślenie, podejmowanie decyzji i komunikację (Basińska, Dziewiątkowska 2012 za: Wetzel i in. 2006), co zasadniczo zmienia efektywność codziennej pracy lekarza, a już szczególnie chirurga wykonującego operacje. Wyniki tych badań pokazały pewną tendencję w wyborze stylu radzenia sobie ze stresem wśród chirurgów - im lekarz starszy oraz pozostający w związku małżeńskim, tym częściej stosuje strategię unikania bądź rezygnacji. Te badania również pokazały, iż chirurdzy starają się przeciwdziałać stresowi, działając i myśląc pozytywnie w pierwszej kolejności, a dopiero następnie, i rzadziej, prosząc o wsparcie innych. Wyniki badań przeprowadzonych wśród lekarzy medycyny rodzinnej wykazały, że stres jest najmniej satysfakcjonującym aspektem ich pracy oraz że ogólne zadowolenie z pracy rośnie wraz z wiekiem (Lewtak, Poznańska, Wysocki 2012).

Należy podkreślić, że im bardziej będą wzmacniane kompetencje osobiste i społeczne, tym lepiej będą sobie radzić lekarze w codziennej pracy zabiegowej i diagnostycznej - zwłaszcza tam, gdzie występuje konieczność szybkiego reagowania.

Nauka radzenia sobie ze stresem powinna rozpocząć się już w trakcie studiów medycznych, podobnie jak wskazywanie na negatywne skutki uzależnień. Potrzebę prowadzenia takich zajęć dostrzeżono i wprowadzono w roku akademickim 2012/2013 na Śląskim Uniwersytecie Medycznym. Niestety nie są to zajęcia obowiązkowe, które - w moim odczuciu - należałoby profilaktycznie rekomendować $\mathrm{W}$ proponowanym bloku z całą pewnością powinny się znaleźć warsztaty z komunikacji, co umożliwiłoby rozwój takich umiejętności, jak asertywność, 8 Informacje ze strony Śląskiej Izby Lekarskiej. 
udzielanie informacji zwrotnych (w tym: niepomyślnych diagnoz), radzenie sobie z oporem i agresywnymi reakcjami pacjentów. Dobra komunikacja pomogłaby również w budowaniu autorytetu lekarza, co jest podstawą skutecznego motywowania pacjentów do zmiany złych nawyków czy niekorzystnego stylu życia, a to w konsekwencji przyczynia się do profilaktyki wielu chorób. Natomiast wzajemne zrozumienie i życzliwy kontakt z pewnością wpływają na okazywanie szacunku, którego brak odczuwają lekarze.

Podobne aspekty kształcenia lekarzy są podnoszone w innych krajach. Przykładowo w Australii dyskutowano konieczność rozszerzenia zajęć z umiejętności komunikacyjnych, empatii i współpracy (Brewster, Rees, Leech, Thompson 2018).

\section{MONITOROWANIE STANU PSYCHOFIZYCZNEGO}

W badaniu podłużnym porównano lekarzy-rezydentów z ich rówieśnikami kończącymi inne studia wyższe i ustalono, że lekarze lepiej oceniają jakość swojego życia, osiągnięcia, perspektywy oraz dobrobyt materialny. Ponadto wykazano, że rezydenci odczuwają silniejszy stres zawodowy, cierpią na słabsze zdrowie oraz mają znacząco mniej przyjaciół niż grupa porównawcza (Walkiewicz, Tartas, Majkowicz, Budziński 2013). W badaniu przeprowadzonym wśród lekarzy pierwszego kontaktu stwierdzono, że są oni zadowoleni ze wsparcia innych lekarzy oraz z relacji z pacjentami i nie odczuwają osamotnienia (Lewtak i in. 2012). Można więc stwierdzić, że o ile nasilenie stresu zależy od specjalności medycznej, to stres jest jednak odczuwany przez każdego medyka, co wymaga wdrożenia rozwiązań przeciwdziałających stresowi zawodowemu. Obecne przepisy milczą na ten temat, a tymczasem należałoby wzmacniać osobiste zasoby lekarzy, umożliwiające skuteczne radzenie sobie ze stresem.

Stwierdzono, że w krajach UE ok. 22\% zaburzeń stanu zdrowia jest rezultatem stresu zawodowego. WHO szacuje, że problem będzie narastał wraz ze starzeniem się społeczeństwa i rozwojem nowych technologii (Waszkowska, Wężyk, Merecz 2013). Zaplanowano powołanie kilku organizacji międzynarodowych, które mają promować dbałość o zdrowie pracowników i warunki pracy poprzez wprowadzanie określonych standardów i efektywnych rozwiązań w zakresie edukacji zdrowotnej i profilaktyki oraz badań wstępnych i okresowych. Szczególnie te ostatnie mogą okazać się skutecznym narzędziem monitorowania stanu zdrowia psychicznego i fizycznego lekarzy. Uważam, że w ich przypadku analizie powinna podlegać nie tylko sfera somatyczna, ale także psychiczna. Stres czy substancje psychoaktywne wpływają negatywnie na podejmowanie decyzji czy szybkość reakcji, co może zaważyć na efektywności leczenia, a tym samym na zdrowiu pacjenta. Przy tym należy podkreślić, że lekarze są świadomi tego typu odpowiedzialności.

Badania okresowe mogłyby mieć dodatkowy element w postaci ustrukturyzowanego lub półustrukturyzowanego wywiadu monitorującego przytoczone zagrożenia. Na podstawie takiego dokumentu lekarz-orzecznik mógłby wskazać na konieczność poddania się leczeniu czy konsultacji psychologicznej lub psychoterapii. Proponowana tematyka wywiadu nawiązuje do klasyfikacji opracowanej w ramach projektu PRIMA-EF (Zarządzanie ryzykiem psychospołecznym - ramowe podejście europejskie) i dotyczy takich aspektów, jak obciążenie 
ciągłymi kontaktami z ludźmi, przeciążenie pracą, zmianowy charakter pracy, kultura organizacji (jakość komunikacji wewnętrznej i współpracy), czy w końcu poczucie izolacji społecznej (Waszkowska i in. 2013). Ponadto w wywiadzie należy uwzględnić czynniki mogące wywoływać choroby zawodowe, czyli omówić jakość i ilość snu, dolegliwości somatyczne utrzymujące się przez ponad 2 tygodnie, regularność posiłków, aktywność fizyczną, ilość i jakość kontaktów społecznych, ilość godzin pracy tygodniowo, konieczność 35-godzinnej przerwy w pracy raz na tydzień. Można także wykorzystać następujące narzędzia, to jest BWAS - Skalę Uzależnienia od Pracy Bergen, Kwestionariusz WART, Skalę Zaabsorbowania Pracą (SZAP), Pracę i Samopoczucie (UWES).

Proponowałabym również systemowe rozwiązanie profilaktyczne, stanowiące obowiązkowy element badania okresowego lekarzy, to jest konsultacje u psychologa klinicznego, jako że pomimo swej wiedzy - lekarze nie są wolni od nałogów, zaburzeń psychicznych, wypalenia zawodowego czy pracoholizmu. Należy też wziąć pod uwagę to, że lekarz-orzecznik może kierować się poczuciem solidarności zawodowej i ukrywać problemy, bądź też niejednokrotnie zostanie okłamany z obawy przed negatywnymi skutkami ujawnienia problemów osobistych.

Dodatkowymargumentem przemawiającymzakonsultacjąpsychologicznąjestwystępowanie przypadków otępienia wśród starszych lekarzy, zwłaszcza przyjmujących w ramach prywatnej praktyki, w trakcie której trudne jest jej dostrzeżenie, a skutkiem mogą być poważne błędy w sztuce lekarskiej ${ }^{9}$. Poza tym nie ma badań weryfikujących stan zdrowia psychicznego studentów medycyny i znane są przypadki ich ukończenia przez chorych na schizofrenię ${ }^{10}$.

Biorąc pod uwagę zarówno aktualne wymogi kwalifikujące na studia medyczne oraz wymagane przepisami procedury orzecznictwa o zdolności do pracy, zaproponowane działania profilaktyczne w postaci edukacji studentów tego kierunku, wsparcia pracujących w zawodzie przez pełnomocnika do spraw zdrowia lekarzy oraz wprowadzenie ustrukturyzowanych elementów badań okresowych pozwoliłoby zapobiec pojawiającym się zagrożeniom. Należy zwrócić uwagę na to, że pewnych czynników z pracy zawodowej lekarza usunąć się nie da, lecz można go na nie przygotować i monitorować ich wpływ.

\section{ZAKOŃCZENIE}

Wymagania i warunki pracy oraz duża liczba zagrożeń czynią pracę lekarza bardzo odpowiedzialną, co obciąża go fizjologicznie i powoduje wysoki poziom stresu, wpływający negatywnie na stan zdrowia. Bezpośrednie kontakty z pacjentami, z chorobami przewlekłymi i śmiercią wymagają wyjątkowych umiejętności komunikacyjnych i skutecznych strategii radzenia sobie z tak silnym obciążeniem.

To głównie czynniki osobowościowe decydują o sukcesie zawodowym, a te nie są weryfikowane w procesie rekrutacji na studia (Walkiewicz 2009), ani też kształtowane w trakcie ich odbywania. Stąd wynikają autorskie propozycje dotyczące kształcenia przyszłych medyków w zakresie takich kompetencji społecznych i osobistych, jak komunikacja i radzenie sobie ze stresem.

9 Informacja od anonimowego autora, przekazana 30.05.2012.

10 Informacja od anonimowego autora, przekazana 30.05.2012. 
Wyniki badań wskazują, że pomimo satysfakcji z życia i zadowolenia z wynagrodzenia, lekarze czują się zestresowani, niedoceniani oraz mają niewiele kontaktów społecznych. Dostępne dane wskazują na zadaniowe podejście do radzenia sobie z trudnościami, ale także na negatywne strategie $\mathrm{w}$ postaci sięgania po alkohol i inne substancje psychoaktywne. Dodatkowym problemem jest późna diagnostyka uzależnień i łatwy dostęp do środków uzależniających. Jednocześnie lekarze nie są skłonni do otwartego dialogu o zagrożeniach. Stąd też wynika propozycja działań profilaktycznych ze stron niezwiązanych ze środowiskiem, jak na przykład spotkanie z pełnomocnikiem do spraw zdrowia czy z psychologiem orzekającym o zdolności do pracy, a także wdrożenie ustandaryzowanego wywiadu adresowanego okresowo do lekarzy medycyny.

Z zawodu lekarza nie można usunąć tak poważnych aspektów, jak obcowanie ze śmiercią, cierpienie ludzi, odpowiedzialność za decyzje i działania medyczne czy wpływ na pacjenta. Wydaje się, że można jedynie ukształtować umiejętności pomocne w skutecznym działaniu w trudnych warunkach. Mimo wielu zagrożeń praca jest dla lekarzy źródłem satysfakcji i nadaje sens ich życiu, o ile potrafią działać efektywnie. 


\section{BIBLIOGRAFIA}

Dudek, Bohdan. 2003. Zaburzenie po stresie traumatycznym. Gdańsk: GWP.

Heszen, Irena. 2013. Psychologia stresu. Warszawa: Wydawnictwo Naukowe PWN.

Kalat, James W. 2017. Biologiczne podstawy psychologii. Warszawa: Wydawnictwo Naukowe PWN.

McGonical, Kelly. 2016. Siła stresu. Gliwice: Wydawnictwo Helion.

Blask, David E., Robert T. Dauchy, Leonard A. Sauer, Jean A. Krause i George Brainard. 2003. Growth and Fatty Acid Metabolism of Human Breast Cancer (MCF-7) Xenografts in Nude Rats: Impact of Constant Light-Induced Nocturnal Melatolin Suppression. "Breast Cancer Research and Treatment" 79(3): 313-320. DOI: https://doi. org/10.1023/A:1024030518065

Basińska, Małgorzata i Kinga Dziewiątkowska. 2012. Strategie radzenia sobie ze stresem w pracy stosowane przez chirurgów zatrudnionych w różnych szpitalach - badanie pilotażowe. „Polski Przegląd Chirurgiczny” (84)2: 129-8.

Bąk-Sosnowska, Monika, Sebastian Kołodziej, Krzysztof Gojdź i Violetta Skrzypulec-Plinta. 2015. Podmiotowe czynniki ryzyka zachować antyzdrowotnych w grupie lekarzy medycyny. „Medycyna Środowiskowa - Environmental Medicine” (18)3: 17-24.

Brewster, David, Charlotte Rees, Michelle Leech i Geoff Thompson. 2018. Kindness and competition: Are we striking the right balance in medical education? "Australasian Medical Journal” 11(5): 313-315.

Irzyniec, Tomasz, Przemysław Konodyba-Szymański i Henryk Szczerba. 2010. Identyfikacja zagrożén oraz ocena ryzyka zawodowego lekarzy medycyny (wstęne wyniki). „Journal of Ecology and Health" 14(6): 295-302.

Jaśko, Jadwiga, Janusz Kasperczyk, Piotr Gościniewicz, Jan Borczykowski, Jarosław Juszczyk, Jan Klimasara, Aleksandra Łukaszek, Łukasz Mazurek i Ewa Oleś. 2006. Stres - jedynie tego nie brakuje lekarzom. „Problemy Higieny i Epidemiologii” 87(3): 198-200.

Kowalczuk, Krystyna, Barbara Jankowiak, Elżbieta Krajewska-Kułak, Wojciech Kułak, Krystyna Klimaszewska, Dorota Kondzior i Beata Kowalewska. 2009. Wpływ agresji na występowanie stresu w środowisku lekarzy. „Roczniki Pomorskiej Akademii Medycznej w Szczecinie" 55(3): 70-75.

Kulik, Małgorzata M. 2008. Cierpienie, które przerasta czyli o wypaleniu lekarzy pracujacych z ludźmi przewlekle chorymi. „Studia z psychologii w KUL” 15: 81-112.

Lewtak, Katarzyna, Anna Poznańska i Mirosław J. Wysocki. 2012. Predyktory satysfakcji zawodowej lekarzy podstawowej opieki zdrowotnej. „Problemy Higieny i Epidemiologii” 93(3): 558-567.

Marcinkowska, Urszula, Karolina Lau i Jadwiga Jośko-Ochojska. 2013. O potrzebie ksztatcenia studentów medycyny $w$ aspekcie wiedzy o stresie $-w$ ramach zajęć fakultatywnych. „Hygeia Public Health” 48(2): 152-155.

Marcinkowski, Jerzy T. 2006. O próbach rozwiązywania problemu uzależnień w zawodach medycznych. „Hygeia Public Health” 46(3): 334-338.

Maslach, Christina. (2001). What have we learned about burnout and health? „Psychology and Health" 16(5): 607-11. DOI: https.//10.1080/08870440108405530 
Nowaczyk, Katarzyna, Michał-Goran Stanisić i Teresa Rzepa. 2016. Staż pracy i płeć lekarza a efektywność komunikowania się z pacjentem. „Medycyna Rodzinna” 2: 55-58.

Ostrowski, Tadeusz M. 2009. Pozytywne i negatywne następstwa zdrowotne pracy lekarza na więcej niż jednym etacie. „Polskie Forum Psychologiczne” 2009(1): 78-89.

Pepłońska, Beata, Neonila Szeszenia-Dąbrowska. 2002. Choroby zawodowe pracowników szpitali. „Medycyna pracy” 53(5): 369-374.

Stryjewski, Piotr J., Agnieszka Kuczaj, Dorota Domal-Kwiatkowska, Urszula Mazurek i Ewa Nowalany-Kozielska. 2016. Wpływ pracy nocnej i zmianowej na zdrowie pracowników. „Przeglad Lekarski” 73(7): 513-515.

Szczyrba-Maroń, Barbara, Agata Wons. 2008. Używanie substancji psychoaktywnych wśród lekarzy jako niekonstruktywny sposób radzenia sobie z trudnymi sytuacjami. „Alkoholizm i narkomania” 21(1): 9-20.

Wallace, Jean E., Jane Lemaire. 2007. On physician well being-you'll get by with a little help from your friends. "Social Science \& Medicine" 64: 2565-2577.

Walkiewicz, Maciej. 2009. Psychologiczne uwarunkowania sukcesu w zawodzie lekarza. Praca doktorska, Gdański Uniwersytet Medyczny, http://pbc.gda.pl/dlibra/ doccontent?id=11405 [Dostęp: 10.02.2019].

Walkiewicz, Maciej, Małgorzata Tartas, Mikołaj Majkowicz i Waldemar Budziński. 2013. Jakość życia lekarzy rezydentów - absolwentów gdańskiego uniwersytetu medycznego. „Annales Academiae Medicae Gedanensis” 43: 89-102.

Waszkowska, Małgorzata, Agata Wężyk i Dorota Merecz. 2013. Zarządzanie ryzykiem psychospołecznym w ochronie zdrowia pracujących. „Medycyna Ogólna i Nauki o Zdrowiu” 19(4): 445-452.

\section{„Only life dedicated to others is worth living”. Difficulties of the medical doctors}

ABSTRACT: The aim of the study was to identify risk and issues in the profession of medical doctors. In the first part the author has studied threats levels connected with various dangerous (traumatic, accidental), harmful (physical, chemical, biological and psychophysical), job requirement and career development opportunities in Poland. In the second part on the basis of the available research results were indicated factors determining the health condition of doctors and were determined by work conditions and work schedules, stress factors and addiction. In the third part was presented actual best practice and possibly answers to this problem which are also kind for the medical doctors.

KEYWORDS: doctor, stress, work satisfaction, prevention 